\title{
Do Firms' Cash Holdings Differ Between Asian Countries? Theory and Empirical Validation
}

\author{
Ben Said Hatem (Corresponding author) \\ Faculty of Law, Economics and Management of Jendouba \\ University of Jendouba, Jendouba, Tunisia \\ E-mail: hatmbensaid@gmail.com
}

Received: April 11, 2016 Accepted: May 5, 2017

doi:10.5296/ber.v7i1.9293 URL: https://doi.org/10.5296/ber.v7i1.9293

\begin{abstract}
This work identifies the factors that explain firms cash holdings (Opler, Pinkowitz, Stulz, and Williamson, 1999). Empirical validation was calculated on two Asian countries: Chine and Japan. To measure of firms cash holdings, we use, alternatively, two measures: Cash ratio approximated as the ratio of cash and equivalents of cash to total assets, and Quick ratio calculated as cash and equivalents of cash to current liabilities. Our samples contain 119 firms from each country for a period of 8 years from 2006 to 2013. Descriptive statistics show that firms from Chine have higher debt and profitability ratios. However, firms in Japan are older than firms in Chine with a mean age of 38,357 years with a minimum of 4 years and a maximum of 121 years. the results report many differences in cash holdings policy between the two countries. Contrary to our hypothesis, firms in China that have higher capital structure ratios have more cash. We concluded to a difference in the effect of firm size and number of employees in the two countries. Older firms in Japan have more cash. Finally, we concluded to a negative and a statistically significant effect of growth opportunities for firms in Japan and China. Firm performance positively influence cash in the two countries.
\end{abstract}

Keywords: Cash holdings, Leverage, Firm performance, Quick ratio, Growth opportunities

\section{Introduction}

Several authors showed interested in analyzing the determinants of firms cash holdings. Jiyoun, Hyunjoon, David (2011) tested the determinants of cash holdings for restaurant. Using a sample of 125 firms for a period of 12 years from 1997 to 2008, the authors highlight a positive and a significant impact of growth opportunities on firms' cash holdings. Furthermore, they conclude that firms that pay more dividends have less cash. Hardin et al. (2009) showed that firms with higher debt ratios, have less cash. Similarly, in our paper, we 
try to identify factors testing firm cash holdings. Our samples consists of firms from two Asian countries: China and Japan. The next section will interpret previous studies that examined factors testing firms cash holdings. In Section 3, we present our sample, the tested models and our variables. Section 4 interprets the descriptive statistics and our empirical results. A sensitivity analysis of our results by activity sectors is made in section 5 . The last section presents and manipulate results.

\section{The Literature Review}

Like the work of Pinkowitz et al. (2006), Kalcheva and Lins (2007), Bates et al. (2009), Guiso et al (2009) and Bottazzi et al ( 2010), Yangyang, Paul, Ghon, Truong and Veeraraghavan (2015) tested differences in cash holdings policy for firms from many regions. The authors begin to highlight the importance of culture of each country in identifying cash holdings policy for each company. Indeed, according to Li et al. (2013) and Kumar et al. (2011), behaviour of managers and outsider investors is manipulated by other factor. Using a sample of 36,987 companies from 102 countries, the authors conclude that individualistic behaviour negatively affects cash holdings policy.

Like Grossman and Helpman (1991), Griliches (1979), Jaffe, Trajtenberg, and Henderson (1993), Almeida, Campello, and Weisbach (2004), Han and Qiu (2007), Jiaping and Chi (2015) test the impact of technology on companies liquidity. The authors presented their research hypotheses according to which a positive impact of technology on cash holdings is assumed. Furthermore, the authors highlight that this positive effect is greater for firms with financials difficulties. Testing a sample of firms from different industries (pharmaceuticals, computers, textile ...), the authors conclude that cash holdings policy of firms with financial difficulties is more sensitive to technology than other firms in good financials situations.

Following the methodology of Opler et al (1999), Booth, Aivazian, Demirgu Kunt, and Maksimovic (2001), Ozkan Ozkan (2004), Ferreira and Vilela (2004), Dittmar and Mahrt-Smith (2007), Basil (2013) tried to identify the financial variables that identify cash holdings. The author examined a sample operating in Brazil Russia, India, China, USA and Great Britain over a period of 7 years from 2002 to 2008. The author started by presenting cash holdings theories (trade-off and pecking order theories). In a second step, the author interpreted the determinants of cash holdings. Studying a sample previously described and used from the DataStream database, the author concluded no correlation between the different variables. The findings present that debt and dividends policy significantly affect firms' cash holdings.

\section{Data and Methodology}

\subsection{Sample Selection}

The data of our sample are obtained from « Mergentonline » database. Our samples consists of 119 firms of Chine, and 119 firms of Japan for a period of 8 years from 2006 to 2013.

\subsection{Choice of Variables and Hypotheses}

The dependent variable: 
Dependent variables

Cash holdings: according to the works of Acharya et al (2013), Almeida et al (2004), Han and Qiu (2007) and Palazzo (2012), we use, alternatively, by two ratios:

- Cash ratio: The first ratio measures the cash holdings approximated by the ratio of cash and equivalent of cash divided by total assets.

- Quick Ratio: This second ratio measures cash holdings as the ratio cash and equivalent of cash divided by current liabilities

The independent variables:

Leverage: according to works of Bates et al (2009), Dittmar et al (2003) and Opler et al (1999), we approximate leverage as the ratio of long term debt increased short-term debt divided by total assets. Generally, firms that own lower cash try to finance their activity by debt. Therefore, leverage negatively explains cash holdings. Hypotheses 1: debt ratio negatively affects cash holdings.

Firm size: firm size is estimated as the logarithm of total assets (Lang et al., 1995). Bankruptcy probability for large firms is low. Then, these firms hold less of cash. However, the larger the firm is, the lower information asymmetry is. Large firms use, in this case external funding with a lower cost, which will enhance cash holdings. Hypotheses 2: firm size negatively or positively affects cash holdings.

Number of employees: increasing the number of managers leads to higher remuneration. Cash holdings decreases. However, an increase of qualified managers enhances operating efficiency, and therefore firms' financial profitability. We conclude, in this case to higher cash holdings. Hypotheses 3: the number of employees negatively or positively affect cash holdings.

Age: generally, age sends a good signal to outsider investors. Then, older firms can obtain more resources at a lower cost. Hypothesis 4: age positively affects cash holdings.

Growth opportunities: Like in Myers and Majluf (1984), we measure growth opportunities as the growth rate of total revenues. Corporations with more opportunities are more likely to hold more cash to finance such future capital projects. Hypotheses 5: growth opportunities positively explain cash holdings.

Firm performance: according to work of Amy and Jan Mahrt (2007), we measure firm performance as the ratio of return on assets that is equal to net income divided by total assets. The most profitable firms hold more cash to pay dividends. Furthermore, an increase in profitability involves higher net income, and therefore more cash. Hypotheses 6: performance positively affects cash holdings. 
Table 1. Variables and expected signs

\begin{tabular}{|c|c|c|c|}
\hline Variables & Abbreviation & Formulation & Expected sign \\
\hline Cash ratio & Cash & Cash and equivalents of cash / TA & Dependant variable \\
\hline Quick ratio & Quick ratio & Cash and equivalents of cash / current liabilities & Dependant variable \\
\hline Leverage & LEV & (LTD+STD)/TA & - \\
\hline Firm size & SIZE & Ln (TA) & $-/+$ \\
\hline $\begin{array}{c}\text { Number of } \\
\text { employees }\end{array}$ & NE & Number of employees & $-/+$ \\
\hline $\begin{array}{c}\text { Firm age } \\
\text { Growth } \\
\text { opportunities }\end{array}$ & GGE & $\begin{array}{c}\text { Number of years between incorporated } \\
\text { year and outstanding yera }\end{array}$ & + \\
\hline $\begin{array}{c}\text { Firm } \\
\text { performance }\end{array}$ & ROA & $\begin{array}{c}\text { Growth rate of total revenues. } \\
\text { TA: total assets. } \text { LTD: Long term debt. STD: Short term debt }\end{array}$ & + \\
\hline
\end{tabular}

\subsection{The Models}

To study the factors explaining firms' cash holdings, we test the following models (Basil Al-Najjar, 2013):

$$
\begin{aligned}
& \text { CASH }_{i t}=\alpha_{0}+\alpha_{1} * L E V_{i t}+\alpha_{2} * S I Z E_{i t}+\alpha_{3} * N E_{i t}+\alpha_{4} * A G E_{i t}+\alpha_{5} * G R O W T H_{i t}+\alpha_{6} * R O A_{i t}+\varepsilon_{i t} \\
& \text { Quick Ratio }_{i t}=\alpha_{0}+\alpha_{1} * L E V_{i t}+\alpha_{2} * S I Z E_{i t}+\alpha_{3} * N E_{i t}+\alpha_{4} * A G E_{i t}+\alpha_{5} * G R O W T H_{i t}+\alpha_{6} * R O A_{i t}+\varepsilon_{i t}
\end{aligned}
$$

\section{The Empirical Results}

\subsection{Descriptive Statistics}

Table 2. distribution of our sample into activity sectors

\begin{tabular}{|c|c|c|c|c|c|c|}
\hline & Manufacturing & Service & Trade & Mining and agriculture & Real estate & Total \\
\hline Chine & 77 & 21 & 10 & 3 & 8 & 119 firms \\
\hline Japan & 55 & 36 & 26 & 0 & 2 & 119 firms \\
\hline
\end{tabular}

Our sample is described into five sectors: service sector, manufacturing sector, service sector, trade sector, mining and agriculture sector and real estate sector are presented in table 2 . The sample of China presented as follow: 77 firms in manufacturing sector, 21 firms in service sector, 10 firms in trade sector, 3 firms in mining and agriculture sector and 8 in real estate sector. A significant part of firms belongs to industrial sector. For the country of Japan : 55 firms in manufacturing sector, 36 firms in service sector, 26 firms in trade sector and 2 in real estate sector.

The results (table3) show that although the china firms are more profitable, they have higher debt ratio with an average mean of 0.489 . The average profit mean of firms in china is 0,0325 . Furthermore, China firms are the largest firms. The average size is 19.957. They employ on average 19,738.5 employees. However, companies from Japan are the older firms with an average age of 38.357, and a growth rate of total revenue of 0.0891. Average cash in Chine and in Japan is 0,291 and 0,328, respectively. These values are higher then founded by Al- 
Najjar and Belghitar (2011).

Table 3. Descriptive statistics

\begin{tabular}{|c|c|c|c|c|c|}
\hline & \multicolumn{4}{|c|}{ Chine } & \multirow[b]{2}{*}{ MAX } \\
\hline & OBS & MEAN & STD DEV & MIN & \\
\hline QR & 707 & 0,529 & 0,241 & 0 & 1 \\
\hline Leverage & 930 & 0,489 & 0,194 & 0,00853 & 0,959 \\
\hline ROE & 933 & 0,0696 & 0,148 & $-0,903$ & 0,998 \\
\hline SIZE & 952 & 19,957 & 1,684 & 13,849 & 25,220 \\
\hline CASH & 947 & 0,291 & 0,168 & 0 & 0,949 \\
\hline NE & 409 & 19738,5 & 51643,58 & 25 & 314541 \\
\hline AGE & 951 & 13,371 & 6,283 & 1 & 61 \\
\hline GROWTH & 829 & 0,735 & 6,0807 & $-0,996$ & 133,975 \\
\hline Volty & 952 & 38,403 & 382,628 & 0,140 & 4192,111 \\
\hline \multirow[t]{3}{*}{ ROA } & 946 & 0,0325 & 0,0770 & $-0,608$ & 0,653 \\
\hline & \multicolumn{4}{|c|}{$\begin{array}{c}\text { Japon } \\
\end{array}$} & \\
\hline & OBS & MEAN & STD DEV & MIN & MAX \\
\hline $\mathrm{QR}$ & 267 & 0,298 & 0,368 & 0 & 1 \\
\hline Leverage & 376 & 0,444 & 0,182 & 0,0496 & 0,984 \\
\hline ROE & 570 & 0,0384 & 0,153 & $-0,969$ & 0,451 \\
\hline SIZE & 590 & 18,732 & 1,424 & 15,197 & 23,560 \\
\hline CASH & 584 & 0,328 & 0,239 & 0 & 0,878 \\
\hline NE & 588 & 1260,15 & 2681,234 & 26 & 21739 \\
\hline AGE & 952 & 38,357 & 22,396 & 4 & 121 \\
\hline GROWTH & 471 & 0,0891 & 0,263 & $-0,854$ & 3,318 \\
\hline Volty & 952 & 2,840 & 7,477 & 0,0295 & 68,779 \\
\hline ROA & 588 & 0,0114 & 0,117 & $-0,788$ & 0,378 \\
\hline
\end{tabular}

\subsection{Determinants of corporate Cash Holdings}

The findings on the factors explaining cash holdings are reported for both countries, China and Japan in the following table. We use, alternatively, two dependent variables: Cash and Quick ratios.

Leverage: the results show that debt negatively affects cash holdings in specification 2 for Japan. This finding do not rejects our first hypothesis (pecking order theory) which stipulates that firms try initially to finance their industries by using internal resources. If firms are still deficient, they use external resources. However, a higher capital structure ratio leads to a more cash in specification 2 for China : in fact, high debt means a higher bankruptcy risk. To minimize this risk, firms often try to maintain more cash.

Firm size: firm size negatively affects cash holdings for China. This finding does not rejects our second hypothesis. Bankruptcy risk of larger corporations is low. Then, these corporations hold less cash. Larger Japanese firms hold more cash (specification 1).

Number of employees: the empirical findings highlight that firms with higher number of managers hold more cash. This result is valid only for Japan. In fact, more employees may improve activity and profitability. This finding does not rejects our third hypothesis. However, we found a negative effect of number of employees on cash holdings for specification 1 for 


\section{Macrothink}

China.

Age: the positive impact of age on cash holdings is checked only in specification 2 for Japan. This result means that older firms hold more cash. Firms in China reports a contrary effect. Indeed, the bankruptcy risk of the oldest firms is low. Therefore, these firms are still trying to invest this cash in profitable projects. Furthermore, these companies may obtain money at a lower cost.

Growth opportunities: the negative interdependence of growth opportunities on cash is checked only in specification 1 and 2 for China and Japan, respectively. This result confirms hypothesis 5. Higher growth opportunities lead to less cash. This result may mean that firms have invested all cash in projects, or they have a lack of cash.

Firm performance: high performance means more cash for Chinese firms and specification 2 for Japan. This finding does not rejects the hypothesis 6. However, profitability negatively affects cash holdings in specification 2 for Japan (Basil Al-Najjar, 2013). This result is not statistically significant. This result means that the most profitable corporations hold less cash.

Table 4. Firms' cash holdings determinants

\begin{tabular}{|l|l|l|l|l|}
\hline & \multicolumn{2}{|c|}{ Chine } & \multicolumn{2}{c|}{ Japon } \\
\hline & \multicolumn{1}{|c|}{ Specification 1 } & Specification 2 & Specification 1 & Specification 2 \\
\hline & \multicolumn{1}{|c|}{ QR } & CASH & \multicolumn{1}{c|}{ QR } & CASH \\
\hline C & $1,243^{* * *}$ & $1,0991^{* * *}$ & $-1,428^{* * *}$ & $0,466^{* * *}$ \\
\hline Leverage & $-0,00996$ & $0,278^{* * *}$ & 0,0718 & $-0,181^{* * *}$ \\
\hline SIZE & $-0,0291^{* * *}$ & $-0,0442^{* * *}$ & $0,0861^{* * *}$ & $-0,00564$ \\
\hline NE & $-0,000000489^{* * *}$ & 0,000000199 & 0,0000127 & $0,0000126^{* * *}$ \\
\hline AGE & $-0,0112^{* * *}$ & $-0,00731^{* * *}$ & $-0,000715$ & $0,00126^{* * *}$ \\
\hline GROWTH & $-0,0112^{* *}$ & $-0,000180$ & $-0,00456$ & $-0,0484^{*}$ \\
\hline ROA & $0,928^{* * *}$ & $0,360^{* * *}$ & $-0,00987$ & $0,182^{* *}$ \\
\hline OBS & 220 & 245 & 17 & 300 \\
\hline $\begin{array}{l}\text { R squared }(\%) \\
\text { Waldchi2 }\end{array}$ & 286,31 & 141,90 & 69,58 & 413,89 \\
\hline Prob> F & 0 & 0 & 0 & 0 \\
\hline
\end{tabular}

Note, ${ }^{* * *},{ }^{* * *}:$ significance at $10 \%, 5 \%$ and $1 \%$ levels respectively.

\section{Cash holdings and the Effect of Activity Sectors}

Like, Opler et al (1999), Ozkan and Ozkan (2004), Bates et al. (2009), Kim et al.(1998), Pinkowitz and Williamson (2001) and Hardin et al. (2009), we examine the impact of activity sectors on firms' cash holdings. We consider five activity sectors: the manufacturing sector, service sector, trade sector, agriculture and mining sector and real estate sector. 
Table 5. Role of activity sectors and firms' cash holdings determinants

\begin{tabular}{|c|c|c|c|c|c|}
\hline & \multicolumn{4}{|c|}{ Japan } & \multirow[b]{2}{*}{ Specification 4} \\
\hline & Specification 1 & \multicolumn{2}{|c|}{ Specification 2} & Specification 3 & \\
\hline & Manufacturing & \multicolumn{2}{|c|}{ Service } & Trade & Real estate \\
\hline & CASH & \multicolumn{2}{|c|}{ CASH } & CASH & CASH \\
\hline $\mathrm{C}$ & $0,712^{* * *}$ & \multicolumn{2}{|c|}{$1,950^{* * *}$} & 0,0357 & 2,746 \\
\hline Leverage & $0,157^{* * *}$ & \multicolumn{2}{|c|}{$-0,381^{* * *}$} & $-0,497^{* * *}$ & $-0,199$ \\
\hline SIZE & $-0,0270^{* * *}$ & \multicolumn{2}{|c|}{$-0,0702^{* * * *}$} & 0,0141 & $-0,230$ \\
\hline $\mathrm{NE}$ & $0,0000308^{* * *}$ & \multicolumn{2}{|c|}{$0,0000237^{* * *}$} & $0,000146^{* * *}$ & 0,000846 \\
\hline AGE & $0,00146^{* * *}$ & \multicolumn{2}{|c|}{$-0,00456^{* * *}$} & 0,000557 & 0,0270 \\
\hline GROWTH & $-0,0115$ & \multicolumn{2}{|c|}{$-0,106$} & 0,00924 & 0,148 \\
\hline ROA & $0,186^{*}$ & \multicolumn{2}{|c|}{$-0,383^{*}$} & $-0,354^{* *}$ & 2,250 \\
\hline OBS & 155 & \multicolumn{2}{|c|}{66} & 63 & 9 \\
\hline $\begin{array}{l}\text { R squared (\%) } \\
\text { Waldchi2 }\end{array}$ & 97,91 & \multicolumn{2}{|c|}{160,37} & 70,55 & 99,65 \\
\hline \multirow[t]{5}{*}{ Prob> F } & 0 & ( & & 0 & 0,0104 \\
\hline & \multicolumn{4}{|c|}{ Chine } & \\
\hline & Specification 1 & Specification 2 & Specification 3 & Specification 4 & Specification 5 \\
\hline & Manufacturing & Service & Trade & Agriculture and mining & Real estate \\
\hline & CASH & CASH & CASH & CASH & CASH \\
\hline $\mathrm{C}$ & $2,109^{* * *}$ & $2,485^{* * *}$ & 0,227 & 4,468 & 1,273 \\
\hline Leverage & $0,336^{* * *}$ & $0,327^{* * *}$ & 0,0836 & $-1,238^{* *}$ & $0,396^{* *}$ \\
\hline SIZE & $-0,0992^{* * *}$ & $-0,110^{* * *}$ & 0,0411 & $-0,0807$ & $-0,0652$ \\
\hline $\mathrm{NE}$ & 0,000000273 & $0,000000837^{* * *}$ & 0,0000000235 & $-0,000238^{* *}$ & $0,00000462^{* *}$ \\
\hline AGE & $0,0204^{* *}$ & $-0,00428^{* * *}$ & $-0,00688$ & 0,0348 & 0,00232 \\
\hline GROWTH & $0,0271^{\text {**** }}$ & 0,0238 & $-0,000288$ & $0,220^{* * *}$ & $-0,0646$ \\
\hline ROA & 0,0458 & 0,307 & 0,0399 & $-2,226$ & 0,523 \\
\hline OBS & 124 & 66 & 22 & 10 & 29 \\
\hline $\begin{array}{l}\mathrm{R} \text { squared }(\%) \\
\text { Waldchi2 }\end{array}$ & 216,52 & 142,42 & $-31,59$ & 98,67 & 87,38 \\
\hline Prob> F & 0 & 0 & 0,9837 & 0,1242 & 0,0537 \\
\hline
\end{tabular}

Note, ${ }^{* * *},{ }^{* * *}:$ significance at $10 \%, 5 \%$ and $1 \%$ levels respectively.

Leverage negatively and significantly modifies cash holdings for the service and trade sectors in Japan and the agriculture and mining sector in China. However, a positive effect is found for the manufacturing sector in Japan and the manufacturing, service and real estate sectors in China. Larger firms operating in the manufacturing and service sectors hold less cash in China and Japan. We found a positive effect of number of employees for all sectors for firms in Japan, except the real estate sector. A similar result was found for the service and real estate sectors in the Chinese market. We conclude to a negative effect for the agriculture and mining sector in China. Older firms hold more cash in the manufacturing sector in China and Japan. A negative effect is found for the service sector in China and Japan. A positive interdependence of growth opportunities is found for the manufacturing and agriculture and mining sectors in Japan. Furthermore, high profitability means more cash. This result is true for the manufacturing sector in China. A negative effect is found for the service and trade sectors in Japan. 


\section{Conclusion}

This paper identifies the factors explaining firms' cash holdings(Opler, Pinkowitz, Stulz and Williamson, 1999; Dittmar and Mahrt-Smith, 2007). The results point to many differences in cash holdings policy. Consistent with our hypothesis, firms with higher capital structure ratios in Japan have less cash. Firm size effect in China is found to be negative. A positive effect is found in Japan. Only for firms in Japan, we concluded that firms with a higher number of employees have more cash. A contradictory result is found in China. Older firms in Japan have more cash. Finally, we concluded to a negative and a statistically significant interdependence of growth opportunities and firm performance in Japan and China. Firm performance positively influence cash holdings for China and Japan. As for the effect of activity sectors on firms cash holdings policies, we found that firms operating in the service and trade activities and with a higher debt ratios in Japan have less cash. A similar result is found for the agriculture and mining sector in China. For firms in China and Japan operating in the manufacturing and service sectors, we have found that the largest firms have less cash. Firms with a high number of managers operating in the manufacturing, service and trade sectors in Japan and the service and real estate sectors in Chine have more cash. we also founded other differences in the other approximations ( growth opportunities and firm performance).

\section{References}

Acharya, V., Almeida, H., \& Campello, M., (2013). Aggregate risk and the choice between cash and lines of credit. Journal of Finance, 68, 2059-2116.

https://doi.org/10.1111/jofi.12056

Almeida, H., Campello, M., \& Weisbach, M. S. (2004). Thecash flow sensitivity of cash. Journal of Finance, 59, 1777-1804. https://doi.org/10.1111/j.1540-6261.2004.00679.x

Al-Najjar, B., \& Belghitar, Y. (2011). Corporate cash holdings and dividend payments: Evidence from simultaneous analysis. Managerial and Decision Economics, 32(4), 231-241. https://doi.org/10.1002/mde.1529

Amy, Dittmara, \& Jan, Mahrt-Smithb. (2007). Corporate governance and the value of cash holdings. Journal of Financial Economics, 83, 599-634.

https://doi.org/10.1016/j.jfineco.2005.12.006

Basil, Al-Najjar. (2013). The financial determinants of corporate cash holdings: Evidence from some emerging markets. International Business Review, 22, 77-88.

https://doi.org/10.1016/j.ibusrev.2012.02.004

Bates, T. W., Kahle, K. M., \& Stulz, R. M. (2009). Why do US firms hold so much more cash than they used to? The Journal of Finance, 64(5), 1985-2021.

https://doi.org/10.1111/j.1540-6261.2009.01492.x

Booth, L., Aivazian, V., Demirgu“ c c-Kunt, A., \& Maksimovic, V. (2001). Capital structures in developing countries. Journal of Finance, 56, 87-130.

https://doi.org/10.1111/0022-1082.00320 


\section{Macrothink}

Business and Economic Research ISSN 2162-4860 2017, Vol. 7, No. 1

Bottazzi, L., Da Rin, M., \& Hellmann, T., (2010). The Importance of Trust for Investment: Evidence from Venture Capital. Working paper, Tilburg University.

Dittmar, A., \& Mahrt-Smith, J. (2007). Corporate governance and the value of cash holdings. Journal of Financial Economics, 83, 599-634. https://doi.org/10.1016/j.jfineco.2005.12.006

Dittmar, A., Mahrt-Smith, J., \& Servaes, H., (2003). International corporate governance and corporate cash holdings. Journal of Financial and. Quantitative Analysis, 38, 111-134. https://doi.org/10.2307/4126766

Ferreira, A., \& Vilela, S. (2004). Why do firms hold cash? Evidence from EMU Countries. European Financial Management, 10(2), 295-319.

https://doi.org/10.1111/j.1354-7798.2004.00251.x

Grossman, G. M., \& Helpman, E. (1991). Innovation and Growth in the Global Economy. MIT Press, Cambridge, MA.

Griliches, Z. (1979). Issuesinassessingthecontributionofresearchand development to productivity growth. Bell Journal of Economics, 10, 92-116. https://doi.org/10.2307/3003321

Guiso, L., Sapienza, P., \& Zingales, L. (2009). Cultural biases in economic exchange? Quarterly Journal of Economics, 124, 1095-1131.

https://doi.org/10.1162/qjec.2009.124.3.1095

Han, S., \& Qiu, J. (2007).Corporate precautionary cash holdings. Journal of Corporate Finance, 13, 43-57.

Hardin, W. G., Highfield, M. J., Hill, M. D., \& Kelly, W. (2009). The determinants of REIT cash holdings. Journal of Real Estate Financial Economics, 39(1), 39-57.

https://doi.org/10.1007/s11146-007-9103-1

Jaffe, A. B., Trajtenberg, M., \& Henderson, R. (1993). Geographical localization of knowledge spillovers from patent citations. Quarterly Journal of Economics, 108, 577-598. https://doi.org/10.2307/2118401

Jiaping, Chi, Wan. (2015). Technology spillovers and corporate cash holdings. Journal of Financial Economics, 115, 558-573. https://doi.org/10.1016/j.jfineco.2014.10.005

Jiyoung, Hyunjoon. (2011). David. Determinants of corporate cash-holding levels: An empirical examination of the restaurant industry. International Journal of Hospitality Management, 30, 568-574. https://doi.org/10.1016/j.ijhm.2010.10.004

Kalcheva, I., \& Lins, K. V. (2007). International evidence on cash holdings and expected managerial agency problems. Review of Financial Studies, 20, 1087-1112.

https://doi.org/10.1093/rfs/hhm023

Kim, C., Mauer, D., \& Sherman, A. (1998). The determinants of corporate liquidity: theory and evidence. Journal of Financial and Quantitative Analysis, 33(3), 335-359.

https://doi.org/10.2307/2331099 
Kumar, A., Page, J., \& Spalt, O. G. (2011). Religious beliefs, gambling attitudes, and financial market outcomes. Journal of Financial Economics, 102, 671-708.

https://doi.org/10.1016/j.jfineco.2011.07.001

Lang, L., Poulsen, A., \& Stulz, R. (1995). Asset sales, firm performance, and the agency costs of managerial discretion. Journal of Financial Economics, 37, 3-37.

https://doi.org/10.1016/0304-405X(94)00791-X

Li, K., Griffin, D., Yue, H., \& Zhao, L. (2013). How does culture influence corporate risk taking? Journal of Corporate Finance, 23, 1-22.

https://doi.org/10.1016/j.jcorpfin.2013.07.008

Myers, S. C., \& Majluf, N. S. (1984). Corporate financing and investment decisions when firms have information that investors do not have. Journal of Financial Economics, 13, 187-221. https://doi.org/10.1016/0304-405X(84)90023-0

Opler, T., Pinkowitz, L., Stulz, R., \& Williamson, R. (1999). The determinants and implications of corporate cash holdings. Journal of Financial Economics, 52, 3-46. https://doi.org/10.1016/S0304-405X(99)00003-3

Ozkan, A., \& Ozkan, N. (2004). Corporate cash holdings: an empirical investigation of UK companies. Journal of Banking and Finance, 28(9), 2103-2134.

https://doi.org/10.1016/j.jbankfin.2003.08.003

Palazzo, D. (2012). Cash holdings, risk, and expected returns. Journal of Financial Economics, 104, 162-185. https://doi.org/10.1016/j.jfineco.2011.12.009

Pinkowitz, L., \& Williamson, R. (2001). Bank power and cash holdings: evidence from Japan. Review of Financial Studies, 14(4), 1059-1082. https://doi.org/10.1093/rfs/14.4.1059

Pinkowitz, L., Stulz, R., \& Williamson, R. (2006). Does the contribution of corporate cash holdings and dividends to firm value depend on governance? A cross-country analysis. Journal of Finance, 61, 2725-2751. https://doi.org/10.1111/j.1540-6261.2006.01003.x

Yangyang, Paul, Y. Ghon Rhee, \& Cameron, Madhu. (2015) National culture and corporate cash holdings around the world. Journal of Banking \& Finance, 50, 1-18.

https://doi.org/10.1016/j.jbankfin.2014.09.018

\section{Copyright Disclaimer}

Copyright for this article is retained by the author(s), with first publication rights granted to the journal.

This is an open-access article distributed under the terms and conditions of the Creative Commons Attribution license (http://creativecommons.org/licenses/by/3.0/). 